\title{
Demographic Changes in China's Farmers: The Future of Farming in China
}

\author{
Zhengzhou Yang ${ }^{1}$ \\ ${ }^{1}$ Graduate School, Chinese Academy of Social Sciences, Beijing, China \\ Correspondence: Zhengzhou Yang, Graduate School, Chinese Academy of Social Sciences, Beijing 102488, \\ China. E-mail: younger9797@163.com
}

Received: February 20, 2013 Accepted: March 28, 2013 Online Published: June 1, 2013

doi:10.5539/ass.v9n7p136 URL: http://dx.doi.org/10.5539/ass.v9n7p136

\begin{abstract}
Farming in China is at a crossroad. Indeed, statistically speaking, the rural population is declining, the average age of farmers is rising, and fewer young people are choosing farming as a vocation. Furthermore, it is projected that the number of farmers in China will continue to decline. As a result, if there are no effective policies put into place to attract the younger generation into farming, China's ability to produce enough food for its people and sustain agriculture development as a whole, along with the overall development of China, will be severely threatened.
\end{abstract}

Keywords: demographic changes, aging farming, household registration, professional farmers, China

\section{Introduction}

Along with the industrialization and urbanization in China, and an aging workforce in the farming community, great changes are reshaping the future of farming in China. For example, the farm population has shrunk and continues to shrink; the major workforce in the farming sector is comprised of the old people; and because of the migration of farmers from the rural to urban settings, in some areas, the farmland has been abandoned and many villages have become empty and deserted. Moreover, the willingness to farm among the younger generation is extremely low. Consequently, these changes have drawn a great deal of attention around the nation. In fact, in recent years, the concern about who will farm in China in the future has become so urgent. In its No.1 Central Document, or First Policy Document of 2012 and 2013, Chinese government gave great attention to the demographic challenges faced by the farmers in China and emphasized priorities to address these problems by developing new types of agricultural operational bodies which include a new type of professional farmers.

However, the effects these demographic changes have had in farming and agriculture in general are not currently obvious. For instance, in 2012, China had an abundant harvest in the production of grain. In the year of 2012, China's total grain production exceeded 589.57 million tons, which was an increase of 18.36 million tons from 2011, or an increase of $3.2 \%$. Indeed, this was the ninth consecutive year of growth, also set a new historical high level. And yet, for a country with a population of more than 1.35 billion people, which accounts for $18.57 \%$ of total global population, China struggles to feed its people by utilizing only $7 \%$ of the world's available land.

With more and more young farmers leaving farming to work in the cities, farming, which is currently comprised of an aging population, is facing a huge threat. For this reason, in this article, I would review China's farmers' demographic changes, examine the factors that contribute to the changes, probe how demographic influences can be expected to shape the future of Chinese farming, predict how all these changes will affect rural China, and attempt to answer the question, "Who will be China's farmers in the future?"

\section{The Basic Background on Chinese Farming}

The first step to understanding Chinese farming begins with what's referred to as household registrations, or hukou system. For example, Chinese society is an urban-rural dual social structure identified by its household registrations, or hukou. According to hukou, Chinese citizens are divided into two classes, either rural or urban. Even though they may work in the cities, rural residents have rural household registration, which is the same for farmers or other agricultural workers. In addition, hukou is not according to where a worker lives, but rather, it is determined on a hereditary basis. That is, for rural residents, even though they work and live in the cities, they will most likely have a rural household registration. Indeed, they are still considered farmers. Furthermore, in 
China, public services are supplied differently according to hukou. As a result, rural residents cannot equally enjoy the public services that urban residents have. For this reason, in China, farmers are considered to be inferior or second-class citizens.

Additionally, because of the reforming and opening policies of 1978, categorizing rural population versus farmers became more complicated. For instance, even though more and more farmers leave the countryside to work in the cities, because of hukou, they are called rural migrant workers. These rural migrant workers seasonally travel back and forth between cities and their homes in the countryside. In fact, most of them work in the cities or in non-agricultural industries during the non-farming season and then return home to sow and harvest their crops during farming season. Thus, farming is only a part-time job for them, while the level of part-time farming is estimated to be very high in Chinese agriculture. Most rural migrant workers are traveling from one city to another to look for living, making it very difficult to record their exact number. For this reason, it is difficult to count the number of the pure farming population, and currently, there is no available data about the exact pure farming population.

Having said that, in this article, agricultural labor force, rural labor force, and rural residents, or population, will all have the same basic meaning as farmers, because any demographic changes in rural residents will be reflected by the demographic changes in the entire farming community.

\section{Demographic State of Chinese Farmers}

\subsection{Reduction in the Number of Farmers}

Though the total population of the country is growing, China's rural population has declined (Table 1). Like any other developed country, the journey of China's development and modernization is the journey of industrialization and urbanization with a reduction in the number of farmers. Indeed, this industrialization and urbanization is the strong powerful force that pulls farmers out of farming. From 1978 to 2012, the rate of urbanization in China was $52.27 \%$, an increase of $34.4 \%$. During that same period, the rate of rural population dropped from $82.10 \%$ in 1978 to $47.43 \%$ in 2012 , or a decline of $34.67 \%$.

Table 1. 1978-2012, the percentage changes of rural and urban residents in China

\begin{tabular}{cccccccc}
\hline Year & 1978 & 1982 & 1990 & 2000 & 2010 & 2011 & 2012 \\
\hline Urban residents & $17.90 \%$ & $21.10 \%$ & $26.40 \%$ & $36.20 \%$ & $49.90 \%$ & $51.27 \%$ & $52.57 \%$ \\
Rural residents & $82.10 \%$ & $78.90 \%$ & $73.60 \%$ & $63.80 \%$ & $50.10 \%$ & $48.73 \%$ & $47.43 \%$ \\
\hline
\end{tabular}

Source: 2012 Statistical Year Book of China, China's National Bureau of Statistics.

Even with the increase of rural migrant workers, the total rural population shrank. In addition, during the same period of time, the agricultural labor force also displayed a steady decline (Table 2). From 2000 to 2011, the number of agricultural laborers dropped from 360 million to 266 million, nearly 100 million farmers. Even though there is no current available data regarding the number of agricultural labor force in 2012, the number of rural migrant workers is an important indicator to the situation of changing in farmers' demography. According to the official analysis of National Bureau of Statistics of China (NBS), since 2000, the number of rural migrant workers began to expand annually by 10 million workers. Additionally, in January 2013, NBS disclosed that in 2012, the total population of rural migrant workers increased 9.83 million people from the previous year, and reached a total of 260 million workers, making this an increase of $3.9 \%$. Truly, the volume of rural migrant workers continues to expand while the population of the farming labor force continues to shrink. 
Table 2. 2000-2011, Chinese demographic changes related agriculture (million)

\begin{tabular}{cccc}
\hline Year & Total population & Rural Population & Agricultural labor force \\
\hline 2000 & 1267 & 808 & 360 \\
2001 & 1276 & 796 & 364 \\
2002 & 1285 & 782 & 366 \\
2003 & 1292 & 769 & 362 \\
2004 & 1300 & 757 & 348 \\
2005 & 1308 & 745 & 334 \\
2006 & 1314 & 732 & 319 \\
2007 & 1321 & 715 & 307 \\
2008 & 1328 & 704 & 299 \\
2009 & 1335 & 689 & 289 \\
2010 & 1341 & 671 & 279 \\
2011 & 1347 & 657 & 266 \\
\hline
\end{tabular}

Source: 2001-2012 Statistical Year Book of China, China's National Bureau of Statistics.

\subsection{Aging Farmers Are a New Concern for China}

Along with the reduction of the rural population and expansion of rural migrant workers, and with more and more young people leaving farming to work in cities or in non-farming industry, it is the elderly who are left behind to do the farming. In fact, among the rural migrant workers, young people are in the majority; but in farming, the elderly are in the majority (Table 3). For instance, in 2011, young rural migrant workers ages 16 to 29 held the largest share of rural migrant workers and accounted for $58.4 \%$; ages 30 to 39 accounted for $23.8 \%$; ages 40 to 49 accounted for $13.10 \%$; ages 50 and over accounted for $4.7 \%$, a sharp reduction in comparison to the other categories. Indeed, for the older rural migrant workers, it is very difficult for them to be employed in the cities or in other non-farming industries, so they will return home to take up farming again.

Table 3. Age distributions of Chinese rural labor force and rural migrant workers in 2011(percent)

\begin{tabular}{lrrrc}
\hline Age & \multicolumn{1}{c}{$16-29$} & \multicolumn{1}{c}{$30-39$} & \multicolumn{1}{c}{$40-49$} & 50 and above \\
\hline Rural labor force & 26.4 & 19.0 & 25.3 & 29.3 \\
Rural migrant worker & 58.4 & 23.8 & 13.1 & 4.7 \\
\hline
\end{tabular}

Source: Survey on new generation of rural migrant workers in 2011,

China's National Bureau of Statistics

Note: The rural migrant workers are those who worked for at least six months in non-farming industries in a year, so the rural labor force included the part-time farmers.

On the other hand, farmers at the age of 50 and over accounted for $29.3 \%$ of total farmers; the age from 40 to 49 accounted for $25.3 \%$; and the age of 40 and over accounted for $54.6 \%$. Having said that, though there is no any available authoritative data about the average age of Chinese farmers, according to some official estimations, in some more developed eastern provinces such as Shanghai, Zhejiang and Jiangsu, which are the richest areas in the mainland of China, the average age of farmers is over 55 years old.

\section{3 The Tendency of Demographic Changes in Farmers}

\subsubsection{Farming Population Will Decline Steadily}

China's rural population is relatively large. In fact, the latest data shows that the rural population at about 640 million, or $47.43 \%$ of China's total population in 2012, reduced almost 15 million from 2011. Even so, the number of farmers is projected to decline steadily in the future. However, China continues to promote the industrialization and the urbanization of the country as shown in the $18^{\text {th }}$ Communist Party of China (CPC) 
National Congress Bulletin of November, 2012. With the rate of urbanization rising, more rural residents will transfer to urban residents and the number of farmers will continue to decrease.

\subsubsection{Aging Farming Will Be the More Generally Pronounced}

Because of the deep-rooted dual social system which is fixed by the household registration, rural migrant workers do not enjoy the benefits of public services like urban residents do, even though migrant workers work and live in cities year around or have houses in the cities. The household registration deters them from enjoying the common social security. The Ministry of Labor and Social Security of China estimated that in 2011, among 260 million rural migrant workers, only 60 million had social security. As a result, most of the rural migrant workers who have no access to equal social security will go back home and farm when they get old because it is too difficult to find a job in the cities.

Furthermore, the willingness to farm among the younger generation is very low. According to a survey conducted by China's NBS, among the young rural migrant workers from the ages 16 to 29 , only $8.8 \%$ showed a likely willingness to live and farm in the countryside (NBS, 2011). Consequently, it can be predicted that farming in China will enter a serious period of time without enough young farmers flowing into farming. Truly, Chinese agricultural development, food security, and even accomplishment of the planned goal of social and economic development will be affected.

\subsubsection{Part-time Farming Will Be Widespread}

Generally, per capita net income of rural residents consists of four sources: household operations, wages and salaries, transfers, and properties. The income from household operations equals the income from purely agricultural undertakings. Since 2005, the share of household operation per capita net income decreased as the percent of wages and salaries rose (Table 4).

Table 4. 2005 to 2011, composition of per capita net income of rural residents in China (percent)

\begin{tabular}{ccccc}
\hline & household operations & wages and salaries & transfer & Properties \\
\hline 2005 & 56.7 & 36.1 & 4.5 & 2.7 \\
2006 & 53.8 & 38.3 & 5.0 & 2.8 \\
2007 & 53.0 & 38.6 & 5.4 & 3.1 \\
2008 & 51.2 & 38.9 & 6.8 & 3.1 \\
2009 & 49.0 & 40.0 & 7.7 & 3.2 \\
2010 & 47.9 & 41.1 & 7.6 & 3.4 \\
2011 & 46.2 & 42.5 & 8.0 & 3.3 \\
\hline
\end{tabular}

Source: 2006-2012 Statistical Year Book of China, China's National Bureau of Statistics.

According to the forecast of China's NBS, the share of per capita household operations at the national average level should be $50 \%$, which means that half or more of per capita net income of rural residents will be from non-farming industries. Thus, the income from wages and salaries would exceed the income from household operations, or agricultural operations. In fact, several years ago, in some of the rich areas in Shanghai and Zhejiang provinces, the income from household operations dropped less than $30 \%$ of total net income while the income from wages and salaries increased to more than $70 \%$ of total net income (NBS, 2010). Truly, Chinese farming has become part-time farming.

In addition, small scale farming also contributes to part-time farming. In China, farming falls under the household contract management system. That is, the farm land is owned collectively and every household obtains the right of contract management of the land through the contract with the collective. But because of the large volume of population of farmers and limited total quantity of farm land, the scale of family farms is very small. In fact, per capita farm land for a rural household is 0.38 acres, allowing a family of five members to farm 1.9 acres. With this in mind, according to the standard labor needs in 2010, it would take less than 70 days from sowing to harvest to farm 1.9 acres land, which means the remainder of the year, the farmers must look for non-farming jobs (NBS, 2011). In fact, the farmer needs to mainly concentrate on planting and harvesting time. Therefore, most of rural migrant workers go back home from cities or other non-farming sectors during planting and harvesting season, leaving the daily field management to be taken by the old who are left at home. 
Furthermore, technological advancements in agricultural machinery, along with seed and pesticide improvements, reduce the amount of work farmers need to do to raise their crops, making it possible to raise as many crops, if not more, with fewer farmers.

\subsubsection{The Willingness to Farm among the Younger Generation Remains Exceedingly Low}

In China, farming also suffers from a social bias. In fact, in its culture and tradition, farming is considered an inferior occupation. For a long time, policy priorities were given to urban development and the urban residents, making the policies which support the rural areas, agriculture, and the farmers, inadequate. Indeed, for most rural areas, especially in the middle and west China, the life of rural people and farming operational conditions are very poor, the infrastructure lags behind the urban, and the gap between rural and urban continues to widen. In addition, the lack of roads and shabby houses, without necessary sanitary provisions and running water, make some Chinese rural areas similar to those have been found in third world nations. Therefore, in a situation of being discriminated by the society and hukou, it is inevitable that the willingness of young people in China to enter farming will be very low. Again, only 8.8 percent of all young rural migrant workers (NBS, 2011), who were born since 1980, showed a willingness to go back home and work in farming.

The young people who would like to run agricultural related operations in rural areas come under great social pressure, especially from their families. In fact, since China reformed its college entrance examination policies in 1977, which allowed students to enter college by taking exams, parents in the rural areas have encouraged their children to focus on education and attending a university, since this was the only way for rural students to change their fate by helping them secure stable work in the cities through state assignments. Since 1949, this has been referred to as receiving an iron bowl. However, in the late 1990s, China reformed its college students' employment policy by abandoning the state assignment, forcing students to look for jobs themselves. That is so called broken iron bowl. But, even so, this change in policy did not deter parents' determination of sending their children to school since they hoped their children could find decent jobs in the cities and not be farmers. Owing to such tradition, some farmers even objected to their own children becoming farmers, since in China, it is shameful for parents if their children choose to be farmers.

Other obstacles for those young people who might want to farm center on policies which cause young farmers to face land, capital, and technology challenges ( $\mathrm{Li}, 2012)$. For instance, in China, young farmers cannot get a loan from banks where they do not have previous accounts. Consequently, more than $40 \%$ of young rural migrant workers are without any contract land (NBS, 2012) and most of the young people who were raised in the rural areas have no farming skills. Thus, for the majority of the younger generation who were raised in the rural areas, their dream is to work and live in the cities (Xinhua, 2013).

\section{The Future of Farming in China: From Demographic Perspective}

\subsection{Can Policy Attract the Young to Enroll in Farming}

China's concern over who will be the next generation of farmers has been reflected in its No.1 Central Document of 2012 and 2013 and the $18^{\text {th }}$ Community Party of China (CPC) National Congress Bulletin. In No. 1 Central Document of 2012, China called for fostering a new type of professional farmers, which was the first time that China put forward the term of new type professional farmers. In addition, in No.1 Central Document of 2013, China asked for strengthening the fostering of a new type operational bodies, or professional farmers. The same proposition appeared in the $18^{\text {th }}$ Community party of China (CPC) National Congress Bulletin.

Though the vision is very desirable, the prospects for success seem daunting. For example, these initiatives still are confined to the household registration; there is no mention of the generalization and equalization of the urban and the rural social security in its document; the farmers will still be second-class citizens; the farmers cannot share basic social respect; and farming will still be the last occupation for rural residents to do.

Additionally, in recent years, China has taken urgent measures to strengthen support for farmers in order to retain the agricultural stability, while, at the same time, to help farmers increase their income and attract the younger generation to farming. Such programs, or initiatives, are concepts without enough authoritative direction to implement these measures.

Even the term of professional farmer is not actually a new term used by the Chinese government, since the term first appeared in the No.1 Central Document of 2005, which emphasized the development of Chinese professional farmers. China conducted a number of projects following 2005, including the Young Farmers Project, which was one of the important projects planned to train eight million young farmers by 2010. But such projects made little improvement on bringing the young worker into farming. Thusly, just like the professional farmers of 2005, currently there is no official or authoritative definition on what kinds of standards should be set 
in place for the new type professional farmers. Moreover, even abolishing the agricultural tax in 2006 and strengthening the subsidies to farmers, which once was applauded as great bounty to the farmers in the century, did not entice the young to come back to farming.

Finally, today's farmers face a multiple of risks, including weather, soaring cost of supplies and equipment, and fluctuations in the market. Consequently, the comparative profits of farming are marginalized and very low. Therefore, it is extremely difficult for farmers to make a stable income as more and more farmers find that it costs more to plant crops than the profit made at harvest time. For example, a farmer farming 1.9 acres of farmland may realize a total profit of about $\$ 700$ from that crop, but it will take almost two months' time in order to draw this income, providing the perfect condition of weather, market and other factors. On the other hand, a building worker in the cities can earn almost $\$ 1000$ in a single month (NBS, 2011).

\subsection{Challenges for Villages, the Rural and Food Security in China}

With the large number of farmers migrating to cities, many villages have become deserted. Indeed, according to a joint research conducted by the Ministry of Culture, the Ministry of Housing and Urban-Rural Development, State Administration of Cultural Heritage, and the Ministry of Finance of China, during the first decade of this century, the number of Chinese villages was reduced from 3.6 million to 2.7 million, which was a net loss of 900 thousand villages. With this trend, every day in China 80 to 100 villages are being deserted, which has an adverse effect on the rural sustainable development on the farming community.

From 2004 to 2012, China has had nine successive years of growth in total grain production. However, it should be noted that the principal farmers who farm, and who are responsible in part for this growth, were born between the late 1940s to the early 1970s, with the majority of those farmers being born in the fifties and sixties. Furthermore, in the next 10 years, many of these farmers will retire simply because they are getting too old to farm. Therefore, without enough young farmers entering the occupation, the question arises, who can take over the farming? Truly, the increasingly aging farming population will pose challenges to the food security for the nation.

\section{Conclusion and Policy Suggestions}

Though at present, the demographic changes in China's farmers did not take any direct impact to Chinese food security and agricultural development, the alarming is around the corner. The aging farming population certainly seems to be an irreversible path for China. Moreover, this aging farming population poses a potential threat to China's development. The changes and its effect are the outcome of its imbalance of social and economic development in China's. The imbalance was out of its institutional arrangement. In order to escape the awkwardness of the imbalance of development, and make sure a sane and all round development in China, China should take the following measures to change its dual-society structure and foster its rural and agricultural development.

First, China should strengthen the population capacity of its cities, by effectively promoting the generalization and equalization of social security among the urban and rural residents and letting more rural residents settle in the cities. Indeed, fewer people living in the countryside is the first requirement for development of scale farming and specialization in agriculture for China.

Next would be the acceleration of the rural development project. More public and financial support should be used for the infrastructure construction of farm living and working conditions in the rural area, including roads, irrigation, electrification, drinking water facilities, and broadband Internet service. Additionally, funds should be allocated from national finance instead of raising revenues from the farmers themselves for such construction.

Since the new type of farmers in China will most likely live in small towns as opposed to villages, the third measure is to stress the importance of developing these small towns. With modern technology, the efficiency of farming will be improved greatly. Therefore, farming will not only be technological labor, but it will also involve management. In addition, the mechanical operation in scale farming makes it possible for farmers to live a ways from their farmland (Zhang, 2012).

Fourthly, all parties need to carry out conservation projects. With this in mind, the government must pay enough attention to the deserted village due to the farmers' migration to the cities and should introduce new conservation projects to such areas to help restore the landscape.

And lastly, pilot programs need to be targeted to young farmers, including special credits and loans to young farmers to help finance farm operations, the leasing of land, and house building.

In summary, comprehensive efforts are needed to address the challenges faced by China in dealing with the 
aging farming community. During the transitional time, China should take steps to improve the farmers' conditions in a comprehensive range and foster the national respect and esteem to the rural way of life, farming, and the farmers.

\section{References}

Cai, F. (2010). Demographic transition, demographic dividend, and Lewis turning point in China. China Economic Journal, 3(2), 107-119. http://dx.doi.org/10.1080/17538963.2010.511899

Chan, K. W., \& Li, Z. (1999). The hukou system and rural urban migration in China: processes and changes. The China Quarterly, 160, 818-855. http://dx.doi.org/10.1017/S0305741000001351

China's National Bureau of Statistics. (2011). Report on volume, structure and features of new generations of rural migrant workers. Retrieved from http://www.stats.gov.cn/tjfx/fxbg/t20110310_402710032.htm

China's National Bureau of Statistics. (n. d.). 1978-2012 China Statistical Yearbook. Beijing: China Statistical Publishing House.

China's National Bureau of Statistics. (n. d.). 2000-2011China Rural Statistical Yearbook. Beijing: China Statistical Publishing House.

Cockshott, W. P. (2011). Comments on the 'China model'. International Critical Thought, 1(2), 148-157. http://dx.doi.org/10.1080/21598282.2011.584159

Cook, S. (1999). Surplus Labor and Productivity in a Chinese Agriculture: Evidence from Household Survey Data. Journal of Development Studies, 35(3), 16-44. http://dx.doi.org/10.1080/00220389908422572

FAO. (2012). Good Practices in Building Innovative Rural Institution to Increase Food Security. Roma: Author.

Gale, F. (1994). America's Aging farmers, Who will Take them? Rural Development Perspective, 8(3), 2-24.

Gilboy, G., \& Heginbotham, E. (2001). China's Coming Transformation. Foreign Affairs, 80(4), 26-39. http://dx.doi.org/10.2307/20050224

Huang, J., \& Ma, H. (1998). The 20 -year reform and the role of agriculture in china: Capital flow from rural tourban and from agriculture to industry. Reform, 5, 56-63.

Lardy, N. (2001). Integrating China into the Global Economy. Washington, D.C. (USA): Brookings Institution.

Li, G. (2012). Who will plant crops in the future? Retrieved from http://www.chinavalue.net/Biz/Blog/2012-6-26/913057.aspx

Li, G., \& Yang, Z. (2012). Survey on Shandong Jinxiang Garlic Market. Shandong Economic Strategy Research, 270(10), 31-34.

Li, J. (1992, March). Rural Reforms and Agricultural Growth in China. The American Economic Review, 82(1), 34-51.

Mary, C. A. (2011). Potential Challenges for Beginning Farmers and Ranchers. Choices, (2), 10-17.

People's Daily. (2012). Farmers rejects his children to farming. Retrieved from http://www.chinanews.com/sh/2012/12-23/4430347.shtml

Solinger, D. J. (1993). China's Transients and the State: A form of Civil Society? Politics \& Society, 21(1), 91-122. http://dx.doi.org/10.1177/0032329293021001005

World Bank, \& The Development Research Center of the State Council. (2012). China 2030. Beijing: Author.

Xinhua News. (2013). The urgent task to solve who will farm tomorrow? Retrieved from http://news.xinhuanet.com/politics/2013-01/15/c_114376795.htm

Zhai, F., \& Wang, Z. (2002). WTO accession, rural labor migration, and urban unemployment in China. Urban Studies, 39(12), 2199-2217. http://dx.doi.org/10.1080/0042098022000033827

Zhang, J. H. (2011). China's success in increasing per capital food production. Journal of Experimental Botany, 62(11), 3707-3711. http://dx.doi.org/10.1093/jxb/err132

Zhang, L., Huang, J., \& Rozelle, S. (2002). Employment, recessions, and the role of education in rural China. China Economic Review, 11(4), 1-16.

Zhang, T. L. (2012). Strengthening the training of new type of professional farmers. Agriculture Machinery Technology Extension, 5, 4-7.

Zhao, Y. (1999). Leaving the countryside: rural-to-urban migration decision in China. American Economic 
Review, 89(2), 281-286. http://dx.doi.org/10.1257/aer.89.2.281

Zhu, Q. Z., \& Yang, H. Q. (2011).Who are engaging in agriculture? China Agricultural University Journal of Social Sciences Edition, 28(1), 162-169.

\section{Notes}

Note 1. No.1 Central Document, or First Policy Document, is the first document released on a yearly basis by the Central Committee of the Communist Party of China. It is the specific word which stands for Chinese government's policy of agriculture, rural and farmers. The No.1 Central Document of 2013 is the ninth consecutive No.1 Cental Document since 2004.

Note 2. Iron Bowl: a special Chinese term means a stable, lifelong job. Before 2000, it means the job that government assigns to the college students when they graduate. Now it means any one who are civil servants, government officials, doctors in public hospitals and employees in the state-owned enterprises and so on, They can have a permanent income they would never lose whether work hard or not.

\section{Copyrights}

Copyright for this article is retained by the author(s), with first publication rights granted to the journal.

This is an open-access article distributed under the terms and conditions of the Creative Commons Attribution license (http://creativecommons.org/licenses/by/3.0/). 